\title{
GENETIC DIVERSITY ANALYSIS OF DENDROCALAMOPSIS BEECHEYANA VAR. PUBESCENS BASED ON ISSR MARKERS
}

\author{
HE, T. Y. ${ }^{1}-$ QU, Y. Q. ${ }^{2}-$ CHEN, L. Y. ${ }^{1}-$ XU, W. ${ }^{2}-$ RONG, J. D. ${ }^{2}-$ CHEN, L. G. ${ }^{2}-$ FAN, L. L. ${ }^{2}-$ \\ TARIN, M. W. K. ${ }^{2}-$ ZHENG, Y. S. ${ }^{1,2^{*}}$ \\ ${ }^{I}$ College of Art \& Landscape Architecture, Fujian Agriculture and Forestry University, Fuzhou \\ 350002, PR China \\ ${ }^{2}$ Bamboo Institute, College of Forestry, Fujian Agriculture and Forestry University, Fuzhou \\ 350002, PR China \\ *Corresponding author \\ e-mail: zsy1960@163.com; phone: +86-591-8378-6894
}

(Received $15^{\text {th }}$ May 2019; accepted $16^{\text {th }}$ Jul 2019)

\begin{abstract}
Dendrocalamopsis beecheyana var. pubescens is native to the southern provinces of China. In this study, the genetic diversity of 17 accessions from 6 populations of Fujian and Guangxi provinces were assessed. Genetic diversity was estimated using ISSR (inter-simple sequence repeat) markers. Sixteen selected primers produced 185 ISSR loci, of which $167(90.27 \%)$ were found to be polymorphic. Dendrogram analyses revealed that the 17 accessions formed six major groups, while the six populations were clustered into three major groups. A high genetic diversity was identified at the species level, with the percentage of polymorphic band $(P P B)$, Nei's gene diversity $(\mathrm{He})$ and Shannon's information index $(I)$ was found to be $90.27 \%, 0.2497$, and 0.3949 , respectively. In addition, Nei's differentiation coefficient (Gst) was relatively high (0.5399) and a low rate of gene flow $(\mathrm{Nm})$ of 0.4261 was observed. The results clearly show that there is a high degree of genetic variation at the species level and a low degree of genetic variation at the population level. Moreover, ISSR molecular markers could be effectively utilized for the characterization of D. beecheyana var. pubescens accessions and identification of the relationships within populations.
\end{abstract}

Keywords: D. beecheyana var. pubescens primers, genetic variation, Fujian, species level

\section{Introduction}

Dendrocalamopsis beecheyana var. pubescens is considered to be an important ornamental bamboo with low cold tolerance, which is widely cultivated in the southern region of Guangdong Province, Hongkong, and Taiwan (Editorial Committee of Chinese Flora of Chinese Academy of Sciences, 1996). In China, this bamboo species is used for the manufacture of construction materials, while the bamboo shoots are used in the traditional Chinese cuisine of Fujian and Guangxi Provinces. In addition, it has been used for soil and water conservation and also to improve the environment in the coastal town of Zhangzhou in Fujian Province (Li et al., 2017). Thus, this bamboo has gained its value for ornamental, ecological, economic, and social purposes and is characterized by its wide adaptability, fast breeding, and highly developed root system (Desai et al., 2015).

To date, genetic diversity analysis of bamboo species has been done with molecular marker variations using PCR amplification (Barkley et al., 2005; Tian et al., 2012; Yang et al., 2012). However, studies on D. beecheyana var. pubescens have been limited to tissue culture, physiological biochemistry, and cultivation techniques with little information reported on genetic diversity. Considering the rich genetic diversity of bamboo species, its genetic diversity analyses can help to determine the genetic 
resources of the species, and also the selection and conservation of improved cultivars.

In recent years, a number of molecular marker technologies have been developed and widely applied in genetic diversity and DNA fingerprinting studies including random amplified polymorphic DNA (RAPD) markers, restriction fragment length polymorphism (RFLP) markers, amplified fragment length polymorphism (AFLP) markers, and inter-simple sequence repeat (ISSR) markers (Grover et al., 2016). RAPD has been regarded as an approach that exhibited high efficiency, sensitivity, and specificity, with rapid and simple method to analyze genomic DNA; however, it is incapable of discriminating between heterozygotes and homozygotes (Williams et al., 1990). The RFLP method offers large numbers of markers, but requires larger quantities of DNA from fresh samples (Yang et al., 1996). Similarly, AFLP markers offer high resolution, stability, and efficiency, but the requirement of high-purity DNA and restriction enzyme makes it expensive to use (Vos et al., 1995). ISSR markers provide a simple, rapid, and highly efficient method that is comparatively economical (Zietkiewicz et al., 1994). Moreover, this technique can detect abundant polymorphic fragments without previous knowledge of the position of the target DNA sequences. Furthermore, ISSR method exhibited high reproducibility since it used long primer lengths and high annealing temperatures (Archak et al., 2003). Due to these advantages, ISSR method was selected to study the analysis of genetic diversity among $D$. beecheyana var. pubescens accessions. In the present study, we applied this approach to estimate the genetic diversity within and among the populations of $D$. beecheyana var. pubescens collected from different regions in Fujian and Guangxi Provinces. Moreover, due to limited information based on ISSR marker few related report about the genetic diversity was compared with other species, such as mango (Luo et al., 2011), cucumber and apricot (Li et al., 2014), and Platycodon grandiflorus (Nie et al., 2014). These analyses provided insights into the germplasm resources and genetic relationships of natural bamboos populations that can help inbreeding improved varieties and for conservation.

\section{Materials and methods}

\section{Plant materials}

A total of 17 accessions of D. beecheyana var. pubescens from 6 natural populations of Fujian and Guangxi Province were used in this study. The geographical location of each population was determined using GPS and are listed in Table 1. The samples were cultivated at the Chishan state-owned forest farm, Dongshan, Fujian, China. Fresh young leaves were collected for the analyses (Fig. 1).

\section{DNA extraction}

Total genomic DNA from each accession was extracted using a Biospin Plant Genomic DNA Extraction kit following the manufacturer's instructions. The qualitative and quantitative analysis of DNA was performed on $1 \%$ agarose gels using an ultraviolet spectrophotometer (NANODROP 2000c Thermo Fisher, Beijing, China). The extracted DNA was diluted to $25 \mathrm{ng} / \mu \mathrm{L}$ and stored at $-20{ }^{\circ} \mathrm{C}$ for future use. 


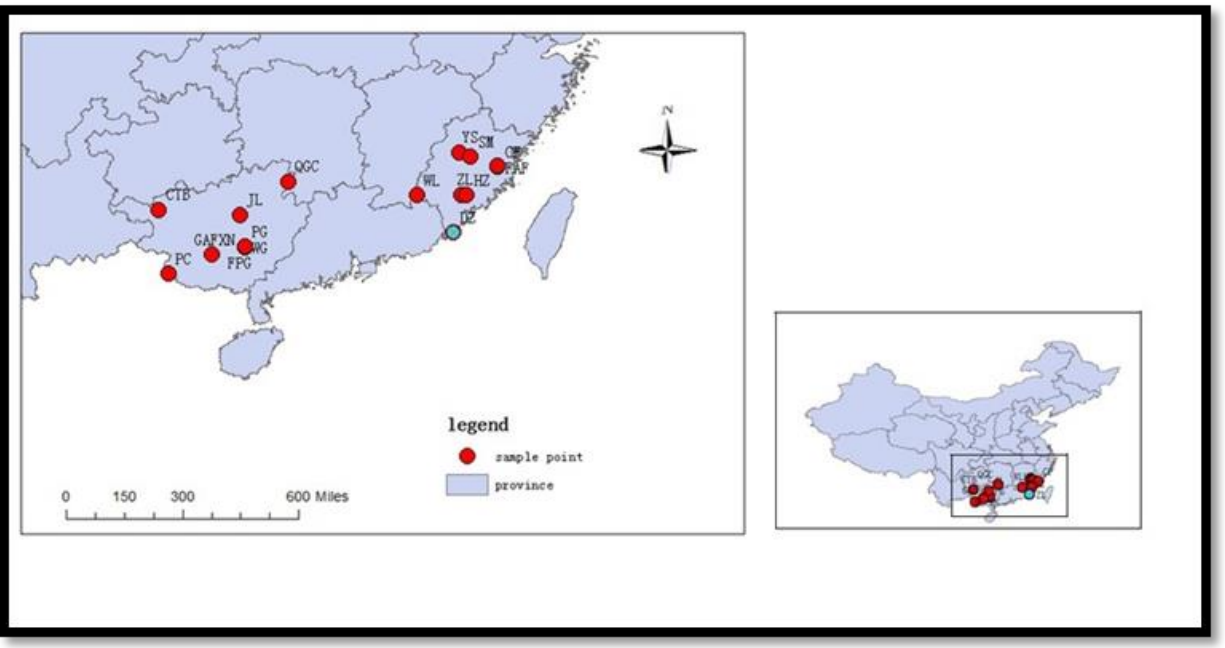

Figure 1. Map showing the origins of accessions

Table 1. Sampling locations of the 17 D. beecheyana var. pubescens accessions

\begin{tabular}{|c|c|c|c|c|c|}
\hline No. & Accession & Population & Location & $\begin{array}{l}\text { Latitude } \\
(\mathbf{N})\end{array}$ & $\begin{array}{l}\text { Longitude } \\
\text { (E) }\end{array}$ \\
\hline 1 & YS & $\begin{array}{l}\text { Western Fujian } \\
\text { Province }\end{array}$ & Yongan, Sanming & $25^{\circ} 98^{\prime}$ & $117^{\circ} 37^{\prime}$ \\
\hline 2 & SM & $\begin{array}{l}\text { Western Fujian } \\
\text { Province }\end{array}$ & Sanming & $26^{\circ} 27^{\prime}$ & $117^{\circ} 62^{\prime}$ \\
\hline 3 & WL & $\begin{array}{l}\text { Western Fujian } \\
\text { Province }\end{array}$ & Wuping, Longyan & $25^{\circ} 01^{\prime}$ & $116^{\circ} 01^{\prime}$ \\
\hline 4 & ZL & $\begin{array}{l}\text { Western Fujian } \\
\text { Province }\end{array}$ & Zhangping, Longyan & $25^{\circ} 03^{\prime}$ & $117^{\circ} 42^{\prime}$ \\
\hline 5 & FAF & $\begin{array}{l}\text { Central Fujian } \\
\text { Province }\end{array}$ & Fujian Academy of Forestry & $26^{\circ} 08^{\prime}$ & $119^{\circ} 03^{\prime}$ \\
\hline 6 & $\mathrm{CF}$ & $\begin{array}{l}\text { Central Fujian } \\
\text { Province }\end{array}$ & Cangshan, Fuzhou & $26^{\circ} 05^{\prime}$ & $119^{\circ} 03^{\prime}$ \\
\hline 7 & $\mathrm{HZ}$ & $\begin{array}{l}\text { Southern Fujian } \\
\text { Province }\end{array}$ & Huaan, Zhangzhou & $25^{\circ} 02^{\prime}$ & $117^{\circ} 53^{\prime}$ \\
\hline 8 & DZ & $\begin{array}{l}\text { Southern Fujian } \\
\text { Province }\end{array}$ & Dongshan, Zhangzhou & $23^{\circ} 07^{\prime}$ & $117^{\circ} 43^{\prime}$ \\
\hline 9 & WG & $\begin{array}{l}\text { Eastern Guangxi } \\
\text { Province }\end{array}$ & Watang Town, Guigang & $23^{\circ} 04^{\prime}$ & $109^{\circ} 36^{\prime}$ \\
\hline 10 & PG & $\begin{array}{l}\text { Eastern Guangxi } \\
\text { Province }\end{array}$ & Pingtian Mountain, Guigang & $23^{\circ} 06^{\prime}$ & $109^{\circ} 36^{\prime}$ \\
\hline 11 & FPG & $\begin{array}{l}\text { Eastern Guangxi } \\
\text { Province }\end{array}$ & $\begin{array}{c}\text { Forest farm of Pingtian Mountain, } \\
\text { Guigang }\end{array}$ & $23^{\circ} 06^{\prime}$ & $109^{\circ} 36^{\prime}$ \\
\hline 12 & GAF & $\begin{array}{l}\text { Southern Guangxi } \\
\text { Province }\end{array}$ & Guangxi Academy of Forestry & $22^{\circ} 49^{\prime}$ & $108^{\circ} 21^{\prime}$ \\
\hline 13 & $\mathrm{XN}$ & $\begin{array}{c}\text { Southern Guangxi } \\
\text { Province }\end{array}$ & Xingning, Nanning & $22^{\circ} 48^{\prime}$ & $108^{\circ} 22^{\prime}$ \\
\hline 14 & $\mathrm{PC}$ & $\begin{array}{c}\text { Southern Guangxi } \\
\text { Province }\end{array}$ & Pingxiang, Chongzuo & $22^{\circ} 05^{\prime}$ & $106^{\circ} 45^{\prime}$ \\
\hline 15 & СТB & $\begin{array}{l}\text { Northern Guangxi } \\
\text { Province }\end{array}$ & $\begin{array}{c}\text { Cen Wang Laoshan Mountain, } \\
\text { Tianlin, Baise }\end{array}$ & $24^{\circ} 29^{\prime}$ & $106^{\circ} 23^{\prime}$ \\
\hline 16 & QGG & $\begin{array}{c}\text { Northern Guangxi } \\
\text { Province }\end{array}$ & Qianjia Dong, Guanyang, Guilin & $25^{\circ} 32^{\prime}$ & $111^{\circ} 13^{\prime}$ \\
\hline 17 & JL & $\begin{array}{c}\text { Northern Guangxi } \\
\text { Province }\end{array}$ & Jinxiu Mountain, Liuzhou & $24^{\circ} 18^{\prime}$ & $109^{\circ} 25^{\prime}$ \\
\hline
\end{tabular}




\section{Primer selection and ISSR-PCR amplification}

In order to select appropriate primers for D. beecheyana var. pubescens, 100 ISSR primer sequences (Supp. Tab 1) provided by the University of British, Columbia (UBC) (https://www.ubc.ca/) in Canada were screened using an optimized ISSR-PCR system by the Shanghai Sangon Biological Engineering Technology Service Co. Ltd., China.

ISSR-PCR amplifications were performed in a total reaction volume of $20 \mu \mathrm{L}$ containing $2.5 \mathrm{mM} \mathrm{MgCl}_{2}, 0.25 \mathrm{mM}$ dNTPs, $1.25 \mathrm{U}$ of Taq DNA polymerase (TaKaRa Biotechnology, Dalian, China), $0.6 \mu \mathrm{M}$ primer, $10 \mathrm{ng}$ genomic DNA, and $2 \mu \mathrm{L} 10 \times$ buffer. The reactions were performed in a TProfessional Thermocycler (Biometra, Gottingen, Germany) with the following conditions: initial denaturation at $94{ }^{\circ} \mathrm{C}$ for $5 \mathrm{~min}$; followed by 40 cycles of $45 \mathrm{~s}$ at $94{ }^{\circ} \mathrm{C}, 30 \mathrm{~s}$ at annealing temperature $\left(50-60{ }^{\circ} \mathrm{C}\right)$, $90 \mathrm{~s}$ at $72{ }^{\circ} \mathrm{C}$; and final extension at $72{ }^{\circ} \mathrm{C}$ for $10 \mathrm{~min}$. The PCR products were stored at $4{ }^{\circ} \mathrm{C}$ until further use. These PCR products $(0.5 \mu \mathrm{g} / \mathrm{mL}$ in $1 \times \mathrm{TBE}$ buffer $(445 \mathrm{mmol} / \mathrm{L}$ Tris, $445 \mathrm{mmol} / \mathrm{L}$ borate, $10 \mathrm{mmol} / \mathrm{L}$ EDTA)) were subjected to electrophoresis on a $1.5 \%$ agarose gel at $120 \mathrm{~V}$ for approximately $1 \mathrm{~h}$ and the gel was later analyzed using Gel Documentation System (Bio-Rad, Hercules, California, USA).

\section{Data analysis}

Polymorphic DNA fragments, obtained with reproducible bands, were scored as present (1) or absent (2). The binary data matrix was analyzed using POPGENE32 (Yeh et al., 2000) to obtain the following genetic diversity parameters within and among populations: percentage of polymorphic bands $(P P B)$, number of alleles $(\mathrm{Na})$, effective number of alleles $(\mathrm{Ne})$, Nei's gene diversity $(\mathrm{He})$, Shannon's information index $(I)$, total genetic diversity $(H t)$, genetic diversity within populations $(H s)$, coefficient of gene differentiation (Gst), and gene flow $(\mathrm{Nm})$. A cluster analysis was performed using the DATA processing system (DPS) program and a dendrogram was constructed using an unweighted pair-group method with arithmetic averaging (UPGMA).

\section{Results}

\section{ISSR polymorphism}

The ISSR primer screening yielded 16 primers exhibiting high polymorphism and stability (Table 2). These ISSR primers generated 185 amplified fragments with an average of 11.6 bands per primer and 167 bands (90.27\%) were polymorphisms. The fragment sizes ranged from 200 to $2200 \mathrm{bp}$ and the number of bands varied from 9 to 15. The highest proportion $(100 \%)$ of the polymorphic bands was obtained with the primers UBC818, UBC826, UBC842, UBC888, and UBC889, while the lowest proportion $(66.67 \%)$ was obtained with the primer UBC850. The results of the amplification using the primer UBC856 for all 17 accessions are illustrated in Figure 2. This example showed the high genetic diversity present in the 17 accessions.

\section{Genetic diversity}

At the species level, $\mathrm{Na}, \mathrm{Ne}, \mathrm{He}, I$ and $P P B$ were found to be 1.9027, 1.3873, 0.2497, 0.3949 and $90.27 \%$, respectively that were relatively higher than populations (Table 3). The accessions from the Western Fujian population exhibited highest values for the genetic diversity parameters, with $\mathrm{Na}=1.5676, \mathrm{Ne}=1.4243, \mathrm{He}=0.2315, \mathrm{I}=0.3358$, 
and $P P B=56.76 \%$. However, genetic diversity in this population was observed to be lower than that at the species level. The lowest level of genetic diversity was found in the Eastern Guangxi population $(\mathrm{Na}=1.1568, \mathrm{Ne}=1.1239, \mathrm{He}=0.0673, \mathrm{I}=0.0968$, $P P B=15.68 \%)$. At the population level, the values for $\mathrm{Na}, \mathrm{Ne}, \mathrm{He}, \mathrm{I}$ and $P P B$ were found to be in the range of 1.1568-1.5676, 1.1239-1.4243, 0.0673-0.2315, 0.09680.3358 , and $15.68-56.76 \%$ respectively. Based on these results, it can be concluded that the highest genetic variations were observed in the Western Fujian population, while the lowest variations were observed in the Eastern Guangxi and Southern Guangxi populations.

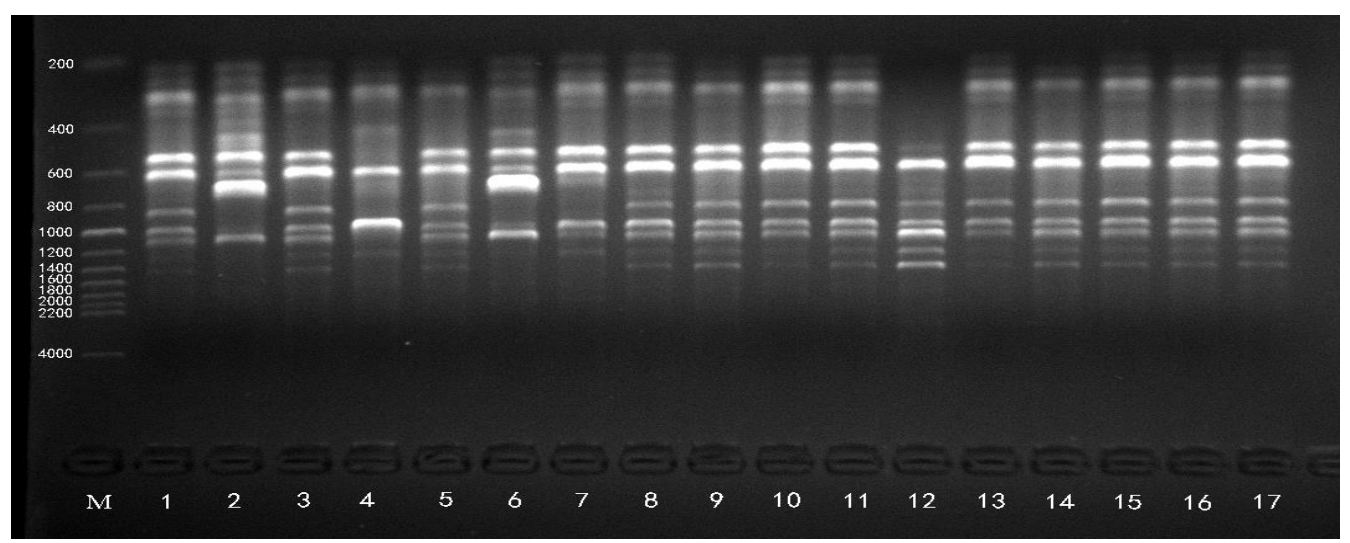

Figure 2. Amplification products from the $17 \mathrm{D}$. beecheyana var. pubescens accessions amplified using the primer UBC856

Table 2. ISSR primers used to analyze D. beecheyana var. pubescens accessions $(R=A, G$; $Y=C, T)$

\begin{tabular}{c|c|c|c|c}
\hline Primers & Sequence $\left(\mathbf{5}^{\prime}-\mathbf{3}^{\prime}\right)$ & Tm $\left({ }^{\circ} \mathbf{C}\right)$ & Number of bands scored & Number of polymorphic bands \\
\hline UBC811 & $(\mathrm{GA})_{8} \mathrm{C}$ & 52.5 & 10 & 9 \\
UBC818 & $(\mathrm{CA})_{8} \mathrm{G}$ & 54.6 & 11 & 11 \\
UBC826 & $(\mathrm{AC})_{8} \mathrm{C}$ & 53.2 & 15 & 15 \\
UBC827 & $(\mathrm{AC})_{8} \mathrm{G}$ & 54.6 & 11 & 10 \\
UBC835 & $(\mathrm{AG})_{8} \mathrm{YC}$ & 56.2 & 10 & 9 \\
UBC836 & $(\mathrm{AG})_{8} \mathrm{YA}$ & 53.9 & 14 & 11 \\
UBC840 & $(\mathrm{GA})_{8} \mathrm{YT}$ & 51.0 & 10 & 9 \\
UBC841 & $(\mathrm{GA})_{8} \mathrm{YC}$ & 53.2 & 9 & 8 \\
UBC842 & $(\mathrm{GA})_{8} \mathrm{YG}$ & 53.2 & 9 & 9 \\
UBC850 & $(\mathrm{GT})_{8} \mathrm{YC}$ & 56.2 & 12 & 8 \\
UBC856 & $(\mathrm{AC})_{8} \mathrm{YA}$ & 53.9 & 13 & 12 \\
UBC857 & $(\mathrm{AC})_{8} \mathrm{YG}$ & 56.2 & 10 & 9 \\
UBC859 & $(\mathrm{TG})_{8} \mathrm{RC}$ & 56.2 & 12 & 10 \\
UBC886 & $\mathrm{VDV}(\mathrm{CT})_{7}$ & 53.0 & 12 & 10 \\
UBC888 & $\mathrm{BDB}(\mathrm{CA})_{7}$ & 53.8 & 12 & 12 \\
UBC889 & $\mathrm{DBD}(\mathrm{AC}) 7$ & 55.0 & 15 & 167 \\
Total & & & 185 & 10.4 \\
Mean & & & 11.6 & \\
\hline
\end{tabular}


Table 3. Genetic diversity between populations of D. beecheyana var. pubescens

\begin{tabular}{c|c|c|c|c|c|c}
\hline Population & Pop ID & $\boldsymbol{N a}$ & $\boldsymbol{N e}$ & $\boldsymbol{H e}$ & $\boldsymbol{I}$ & $\boldsymbol{P P B}(\boldsymbol{\%})$ \\
\hline Western Fujian Province & WF & 1.5676 & 1.4243 & 0.2315 & 0.3358 & 56.76 \\
Central Fujian Province & CF & 1.4000 & 1.2828 & 0.1657 & 0.2419 & 40.00 \\
Southern Fujian Province & SF & 1.4378 & 1.3096 & 0.1814 & 0.2648 & 43.78 \\
Eastern Guangxi Province & EG & 1.1568 & 1.1239 & 0.0673 & 0.0968 & 15.68 \\
Southern Guangxi Province & SG & 1.1568 & 1.1267 & 0.0684 & 0.0979 & 15.68 \\
Northern Guangxi Province & NG & 1.2000 & 1.1679 & 0.0895 & 0.1274 & 20.00 \\
Average & & 1.3198 & 1.2392 & 0.1340 & 0.1941 & 31.98 \\
Average species level & & 1.9027 & 1.3873 & 0.2497 & 0.3949 & 90.27 \\
\hline
\end{tabular}

Na: number of alleles; Ne: effective number of alleles; I: Shannon's information index; He: Nei's gene diversity; PPB: percentage of polymorphic bands

\section{Genetic differentiation and relationships}

From Nei's genetic diversity, genetic differentiation (Gst) was estimated as 0.5399, indicating that $53.99 \%$ of the genetic variation was distributed within populations. The level of the gene flow $(\mathrm{Nm})$ was found to be 0.4261 individuals per generation within the six populations, thus, demonstrating that there was minimum gene flow between the populations (Table 4).

Table 4. Nei's analysis of genetic variability of the six populations

\begin{tabular}{c|c|c|c|c}
\hline & $\boldsymbol{H t}$ & $\boldsymbol{H s}$ & $\boldsymbol{G s t}$ & $\boldsymbol{N m}$ \\
\hline Mean & 0.2912 & 0.1340 & 0.5399 & 0.4261 \\
SD & 0.0253 & 0.0082 & & \\
\hline
\end{tabular}

Ht: total genetic diversity; Hs: genetic diversity within populations; Gst: coefficient of gene differentiation; Nm: gene flow

Genetic diversity was assessed using genetic distances $(D)$ and genetic similarity coefficients $(G S C)$. It was observed that $D$ ranged from 0.0564 (between Western Fujian and Central Fujian populations) to 0.4590 (between Southern Fujian and Eastern Guangxi populations) and GSC ranged from 0.6319 (between Southern Fujian and Eastern Guangxi populations) to 0.9451 (Western Fujian and Central Fujian populations) (Table 5). This analysis showed similar trends in $D$ and GSC levels. The highest GSC (0.9451) and the lowest $D(0.0564)$ were found between the Western Fujian and Central Fujian populations, indicating the closest relationship between them. Moreover, the lowest GSC (0.6319) and the highest $D(0.4590)$ were found between the Southern Fujian and Eastern Guangxi populations, indicating a distant relationship was between these populations.

The UPGMA tree that was constructed based on genetic distance $(D)$ demonstrated that the 17 accessions clustered into six groups (Fig. 3a). Group A, C, E and F comprised one accession each, FAF, JL, DZ and HZ respectively. However, Group B consisted of eleven accessions, namely, YS, SM, ZL, CTB, QGG, GAF, PG, FPG, PC, $\mathrm{XN}$, and WG. Group D consisted two accessions, WL and CF. An UPGMA tree constructed from the population data generated three clusters (Fig. 3b). Cluster I 
included two populations (WF and CF), cluster II contained three populations (EG, SG and NG), and cluster III consisted one population (SF).

Table 5. Nei's (1978) genetic similarity coefficient (GSC) (above diagonal) and genetic distance $(D)$ (below diagonal) between populations

\begin{tabular}{c|c|c|c|c|c|c}
\hline Pop ID* & WF & CF & SF & EG & SG & NG \\
\hline WF & $* * * *$ & 0.9451 & 0.7410 & 0.8669 & 0.8697 & 0.8728 \\
CF & 0.0564 & $* * * *$ & 0.7911 & 0.8295 & 0.8073 & 0.8004 \\
SF & 0.2998 & 0.2343 & $* * * *$ & 0.6319 & 0.6368 & 0.6717 \\
EG & 0.1428 & 0.1869 & 0.4590 & $* * * *$ & 0.9339 & 0.8912 \\
SG & 0.1396 & 0.2141 & 0.4513 & 0.0684 & $* * * *$ & 0.9071 \\
NG & 0.1360 & 0.2226 & 0.3979 & 0.1151 & 0.0976 & $* * * *$ \\
\hline
\end{tabular}

*The identities of the various populations are explained in Table 3

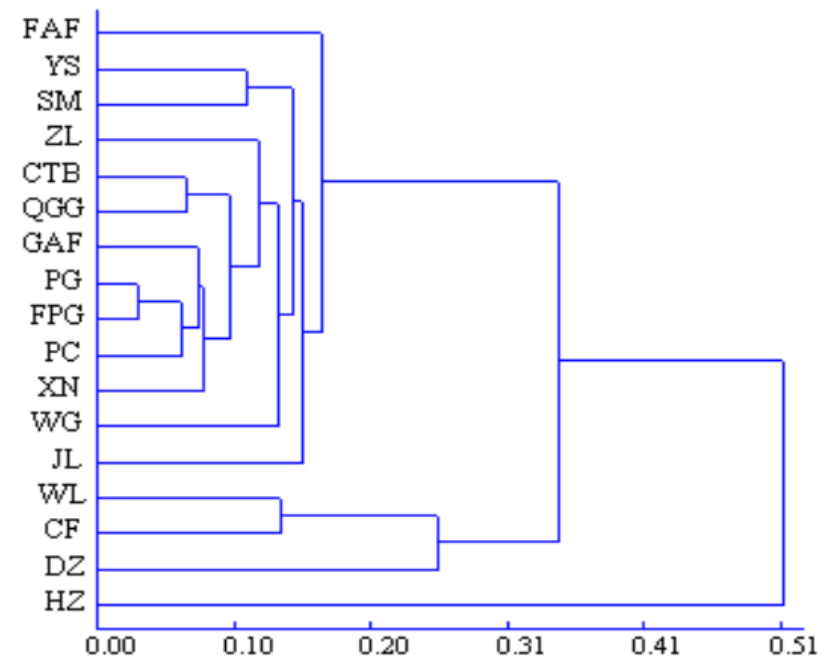

(a)

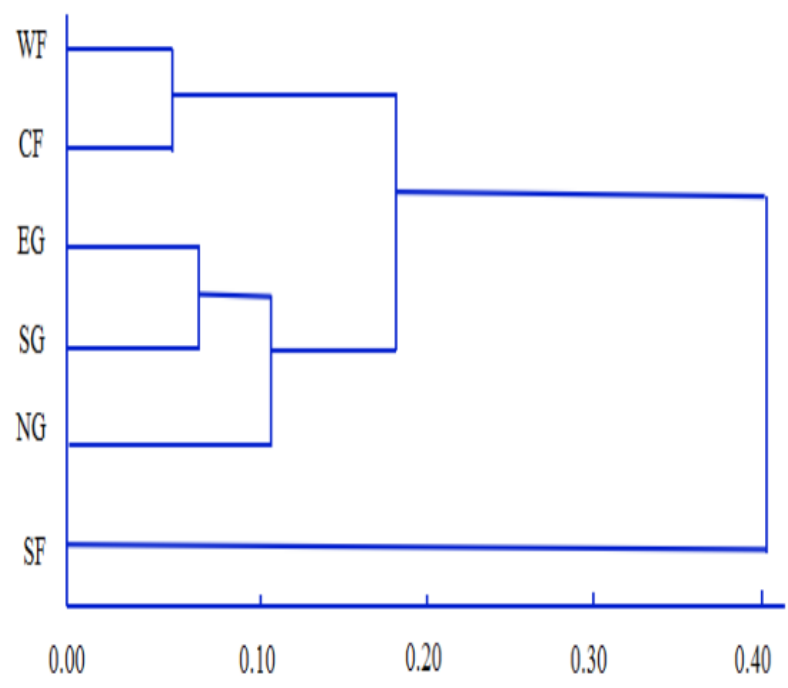

(b)

Figure 3. UPGMA dendrogram of D. beecheyana var. pubescens based on genetic distances indicating the clustering relationships of accessions $(a)$ and populations $(b)$ 


\section{Discussion}

\section{Polymorphism analysis}

In this study, after a preliminary screening of 100 ISSR primers, those primers were selected that showed clear, reproducible, and polymorphic bands. The primers that generated fuzzy bands or failed to generate an amplification product were rejected, including those that showed monomorphic bands due to the formation of dimers in the primers. The 16 selected primers were used for the analysis of the $17 \mathrm{D}$. beecheyana var. pubescens accessions. The selected primers produced an average of 11.6 bands, which is lower than that observed in other bamboo species (Desai et al., 2015). The present study confirmed that the selection of competent primers is very important when using ISSR markers (Safaei et al., 2016).

\section{Genetic diversity}

Genetic diversity data is an essential component of a breeding program. In the present study, 17 accessions of $D$. beecheyana var. pubescens showed higher levels of genetic diversity at the species level compared to the population level. However, the accessions demonstrated relatively high levels of diversity within the six populations. These results are consistent with the data reported in Jatropha previously (Arolu et al., 2015). It was observed that the genetic diversity of $D$. beecheyana var. pubescens $\left(P P B_{s}=90.27 \%, H_{s}=0.2497\right)$ at the species level was higher than that of the shortlived perennial species Blysmus sinocompressus $\left(P P B_{s}=74.76 \%, \mathrm{He}_{s}=0.1668\right)(\mathrm{Hu}$ et al., 2016) and mating breeding system species Platycodon grandiflorum $\left(P P B_{s}=76.29 \%, H_{s}=0.2326\right)(\mathrm{Nie}$ et al., 2014). At the population level, the average $\mathrm{He}_{p}$ in $\mathrm{D}$. beecheyana var. pubescens was 0.1340 (Table 3 ) that was almost similar to that of Taxus fuana (0.1165) (Shah et al., 2008) but lower than that of apricot (0.1738) (Liu et al., 2016). Low $\mathrm{He}_{p}$ value is attributed to low genetic diversity. Similarly, the low average value of $I_{p}(0.1941)$ also indicated a low level of genetic diversity (Table 3). High value have been reported in Portulaca oleracea $\left(I_{p}=0.515\right)$ (Alam et al., 2015). Further, the average value for $P P B_{s}$ was found to be $31.98 \%$ that was lower than that of Platycodon longiflorum $\left(P P B_{s}=55.67 \%\right)$ (Nie et al., 2014). Low genetic diversity within populations has been reported in other plant species, such as Taxus fuana (Shah et al., 2008) and Monimopetalum chinense (Xie et al., 2005).

Our results indicated that $D$. beecheyana var. pubescens showed considerable genetic variation between populations and high genetic diversity within populations. A mixed mating system has been recognized as an important factor to determine the level of genetic diversity in a plant species (Godt et al., 2001). However, other factors can also influence the genetic variation including, the geographic factor that can exhibits significant negative effect on genetic diversity and higher temperatures that can boost the seedling growth and increase genetic diversity. However, D. beecheyana var. pubescens flowers every 10-120 years in an unpredictable mode. The propagation is mainly dependent on selfing by underground rhizomes. Thus, in the present study, the breeding system was not likely to be a contributor towards genetic diversity.

Two possible explanations can be proposed for the high total genetic diversity within populations. Firstly, since $D$. beecheyana var. pubescens lives for many years before flowering, it is highly possible that habitat heterogeneity of the long-lived plants could have contributed to the pattern of genetic diversity in this species (Hu et al., 2016). Secondly, the geographical prevalence of this species might have supported high 
genetic diversity compared to a species with restricted distribution (Godt and Hamrick, 1996). The populations of $D$. beecheyana var. pubescens examined in this study were narrowly distributed in Fujian and Guangxi Provinces. This restricted distribution might have resulted into low genetic diversity among populations (Ge et al., 2005).

\section{Genetic differentiation and relationships}

Various factors such as life history, geographic distribution, and gene flow within populations can influence the genetic structure of plant species (Hilfiker et al., 2004). In this study, we found that the genetic differentiation coefficient among populations of $D$. beecheyana var. pubescens $(G s t=0.5399)$ was higher than the average of other longlived species $(G s t=0.19)($ Nybom, 2004). This suggested that there was a high level of genetic differentiation in $D$. beecheyana var. pubescens. However, genetic variation in D. beecheyana var. pubescens in the Fujian and Guangxi Provinces was mainly observed at the intra-population level (53.99\%) and inter-population level $(46.01 \%)$. This can be attributed to the geographical location that might have had a significant influence on genetic differentiation leading to the higher genetic diversity at the intrapopulation level (Yuan et al., 2007). In addition, the complex topography of the region, including remote and isolated mountains, may have hindered the gene flow between populations, thus promoting population differentiation (Wheeler et al., 2011). In the present study, gene flow among $D$. beecheyana var. pubescens populations was found to be 0.4261 that indicated limited level of gene flow between populations and thus it could not prevent genetic differentiation at the intra-population level.

Genetic diversity was estimated using genetic distance $(D)$ and genetic similarity coefficients $(G S C)$, which ranged from $0.0564-0.4590$ and $0.6319-0.9451$, respectively. This range was consistent with a previous study that reported a range of $0.045455-$ 0.454545 for $D$ (Yuan et al., 2014), however, the GSC range (0.39-0.95) was lower compared to our study (Noroozisharaf et al., 2015). The GSC obtained from our ISSR analysis exhibited a high genetic diversity among $D$. beecheyana var. pubescens accessions. Moreover, the 17 accessions were found to form six major groups in the UPGMA dendrogram. The clustering in this dendrogram was not consistent with the geographical distribution, suggesting that there was no obvious correlation between genetic distance and geographic distance of accessions in Fujian and Guangxi Province. However, the 6 populations clustered into three major groups in the UPGMA dendrogram, and in particular, three populations, EG, SG and NG, formed a cluster with high genetic similarities due to the same place of origin. Therefore, based on the findings of this study, it can be concluded that the geographic distribution may have influenced the genetic distance or the genetic relationships of populations and the widespread accessions may have exhibited higher level of genetic diversity than the narrowly distributed ones. The population SF was found to be grouped away from other two groups, thus, supporting the hypothesis that these D. beecheyana var. pubescens accessions origin from SF were the independent species. Therefore, a high level of genetic variation can be estimated in widespread accessions.

\section{Economical aspects and fiscal policy consideration}

D. beecheyana var. pubescens as one of the protection forest was introduced to coastal regions of southern and eastern China for soil and water conservation and to improve the environment as well. Since, the southeast coast of China has been suffering 
from typhoons, storm surges and other natural disasters throughout the year, it is crucial to strengthen the coastal shelterbelt system to minimize economic losses. Certainly, some capital investments and fiscal policies would be required to conserve the coastal shelterbelt. In this context, this study provided important genetic information for devising the conservation strategies of $D$. beecheyana var. pubescens.

One primary objective of conservation is to protect the genetic diversity. Considering the low genetic diversity among populations and high genetic variation within populations of $D$. beecheyana var. pubescens in China, the most effective strategy for maintaining genetic variation is to conserve and cultivate as many populations as possible. Moreover, transplanting individuals from other populations would enhance inter-population gene flow and genetic diversity. Thus, the foremost step for all populations in situ must be the prevention of the anthropogenic disturbance. Subsequently, we should make it a priority to cultivate the high genetic diversity of $D$. beecheyana var. pubescens in initial period. Since the WF population exhibited the highest level of genetic diversity, it should be preferred for cultivation. Further, the population with high genetic diversity may have the ability to adapt to the environment as compared to the population with low genetic diversity. For ex situ conservation, a germplasm bank is required to be established for this species.

\section{Conclusion}

In this study, the ISSR markers were found to be viable for detecting the high level of genetic diversity within populations and considerable genetic differentiation among populations. In addition, the polymorphism generated by ISSR markers was very high. Based on the findings of this study, it was observed that rich genetic diversity existed in D. beecheyana var. pubescens. Besides, the genetic differentiation and relationships obtained in this study may help in understanding and evaluating the conservation in China. The cluster results of 17 materials related to adaptability, resistance, water and soil conservation and growth period, which need to be further studies. It is necessary to strengthen the collection, identification and excavation of the germplasm resources of D. beecheyana var. Pubescens to enrich the genetic diversity of breeding materials.

Acknowledgements. This work was supported by the Central Fiscal Forestry Science and Technology Extension Project [2013, NO. 7], the Science and Technology Major Projects of Fujian Province [2013NZ0001], the Regional Development Project of Fujian Province [2015 No.3015], Research Development Fund of Fujian Agriculture and Forestry University [KF2015085] and [CXZX2017119], Program for Scientific and Technological Innovation Team for Universities of Fujian Province [2018 No.49].

\section{REFERENCES}

[1] Alam, M. A., Juraimi, A. S., Rafii, M. Y., Hamid, A. A., Arolu, I. W., Latif, M. A. (2015): Genetic diversity analysis among collected purslane (Portulaca oleracea, L.) accessions using ISSR markers. - C. R. Biol. 338: 1-11.

[2] Archak, S., Gaikwad, A. B., Gautam, D., Rao, E. V., Swamy, K. R., Karihaloo, J. L. (2003): Comparative assessment of DNA fingerprinting techniques (RAPD, ISSR and AFLP) for genetic analysis of cashew (Anacardium occidentale L.) accessions of India. Genome 46: 362-369. 
[3] Arolu, I. W., Rafii, M. Y., Hanafi, M. M., Mahmud, T. M. M., Askani, S., Abdullah, N. A. (2015): Genetic divergence and evaluation of yield potential of Jatropha curcas accessions collected from peninsular Malaysia. - Pertanika J. Trop. Agric. Sci. 38: 127142.

[4] Barkley, N. A., Newman, M. L., Wang, M. L., Hotchkiss, M. W., Pederson, G. A. (2005): Assessment of the genetic diversity and phylogenetic relationships of a temperate bamboo collection by using transferred EST-SSR markers. - Genome 48: 731-737.

[5] Desai, P., Gajera, B., Mankad, M., Shah, S., Patel, A., Patil, G., Narayana, S., Kumar, N. (2015): Comparative assessment of genetic diversity among Indian bamboo genotypes using RAPD and ISSR markers. - Mol. Biol. Rep. 42: 1265-73.

[6] Editorial Committee of Chinese Flora of Chinese Academy of Sciences (1996): Flora Reipublicae Popularis Sinicae. - Science Press, Beijing.

[7] Ge, X. J., Zhou, X. L., Li, Z. C., Hsu, T. W., Schaal, B. A., Chiang, T. Y. (2005): Low genetic diversity and significant population structuring in the relict Amentotaxus argotaenia complex (Taxaceae) based on ISSR fingerprinting. - J. Plant Res. 118: 415422.

[8] Godt, M. J. W., Hamrick, J. L. (1996): Genetic diversity and morphological differentiation in Liatris helleri, (Asteraceae), a threatened plant species. - Biodivers. Conserv. 5: 461-471.

[9] Godt, M. J. W., Hamrick, J. L., Edwards-Burke, M. A., Williams, J. H. (2001): Comparisons of genetic diversity in white spruce (Picea glauca) and jack pine (Pinus banksiana) seed orchards with natural populations. - Can. J. Forest Res. 31: 943-949.

[10] Grover, A., Sharma, P. C. (2016): Development and use of molecular markers: past and present. - Critical Reviews in Biotechnology 36: 1-13.

[11] Hilfiker, K., Holderegger, R., Rotach, P., Gugerli, F. (2004): Dynamics of genetic variation in Taxus baccata: local versus regional perspectives. - Can. J. Bot. 82: 219-227.

[12] Hu, Y. P., Bao, R., Shi, L., Wang, J. K., Wang, J., Wang, L., Li, Y. (2016): Analysis of population structure of Blysmus sinocompressus, in the Qilian mountains by ISSR markers. - Aquat. Bot. 134: 54-60.

[13] Li, M., Zhao, Z., Miao, X. (2014): Genetic diversity and relationships of apricot cultivars in north China revealed by ISSR and SRAP markers. - Sci. Hort. 173: 20-28.

[14] Li, S. X., Li, M. F., Ping, Y., Fan, Y. M., Shou, J. N., Sun, R. C. (2017): Valorization of bamboo by $\gamma$-valerolactone/acid/water to produce digestible cellulose, degraded sugars and lignin. - Biores. Technol. 230: 90-96.

[15] Liu, J., Liao, K., M, Nasir., Peng, X. (2016): Analysis of genetic diversity of the apricot germplasm in the southern region of the Tianshan Mountains in Xinjiang, China using the ISSR technique. - Eur. J. Hort. Sci. 81: 37-43.

[16] Luo, C., He, X. H., Chen, H., Ou, S. J., Gao, M. P., Brown, J. S., et al. (2011): Genetic diversity of mango cultivars estimated using scot and ISSR markers. - Biochem. System. Ecol. 39: 676-684.

[17] Nie, C., Liu, R., Li, S., Li, Y. (2014): Assessment of Platycodon grandiflorum germplasm resources from northern Anhui province based on ISSR analysis. - Molecular Biology Reports 41: 8195-8201.

[18] Noroozisharaf, A., Hatamzadeh, A., Lahiji, H. S., Bakhshi, D. (2015): Genetic diversity of endangered primrose (Primula heterochroma Stapf.) accessions from Iran revealed by ISSR and IRAP markers. - Sci. Hort. 190: 173-178.

[19] Nybom, H. (2004): Comparison of different nuclear DNA markers for estimating intraspecific genetic diversity in plants. - Mol. Ecol. 13: 1143-1155.

[20] Safaei, M., Sheidai, M., Alijanpoor, B., Noormohammadi, Z. (2016): Species delimitation and genetic diversity analysis in salvia with the use of issr molecular markers. - Acta Botanica Croatica 75: 45-52. 
[21] Shah, A., Li, D. Z., Gao, L. M., Li, H. T., Möller, M. (2008): Genetic diversity within and among populations of the endangered species Taxus fuana, (Taxaceae) from Pakistan and implications for its conservation. - Biochem. System. Ecol. 36: 183-193.

[22] Tian, B., Yang, H. Q., Wong, K. M., Liu, A. Z., Ruan, Z. Y. (2012): ISSR analysis shows low genetic diversity versus high genetic differentiation for giant bamboo, Dendrocalamus giganteus (Poaceae: Bambusoideae), in China populations. - Genet. Res. Crop Evol. 59: 901-908.

[23] Vos, P., Hogers, R., Bleeker, M., Reijans, M., Van, d. L. T., Hornes, M., Frijters, A., Pot, J., Peleman, J., Kuiper, M., Zabeau, M. (1995): AFLP: a new technique for DNA fingerprinting. - Nucleic Acids Res. 23: 4407-14.

[24] Wheeler, N. C., Jech, K. S., Masters, S. A., O’Brien, C. J., Stonecypher, R. W., Timmons, D. W., Lupkes, A. (2011): Genetic variation and parameter estimates in Taxus brevifolia (Pacific yew). - Can. J. Forest Res. 25: 1913-1927.

[25] Williams, J. G., Kubelik, A. R., Livak, K. J., Rafalski, J. A., Tingey, S. V. (1990): DNA polymorphisms amplified by arbitrary primers are useful as genetic markers. - Nucleic Acids Res. 18: 6531-5.

[26] Xie, G., Wang, D., Yuan, Y., Xuejun, G. E. (2005): Population genetic structure of Monimopetalum chinense (Celastraceae), an endangered endemic species of eastern China. - Ann. Bot. 95: 773-777.

[27] Yang, H. Q., An, M. Y., Gu, Z. J., Bo, T. (2012): Genetic diversity and differentiation of Dendrocalamus membranaceus (Poaceae: Bambusoideae), a declining bamboo species in Yunnan, China, as based on inter-simple sequence repeat (ISSR) analysis. - Int. J. Mol. Sci. 13: 4446-4457.

[28] Yang, W., Oliveira, A. C. D., Godwin, I., Schertz, K., Bennetzen, J. L. (1996): Comparison of DNA marker technologies in characterizing plant genome diversity: variability in Chinese sorghums. - Crop Sci. 36: 1669-1676.

[29] Yeh, F. C., Yang, R., Boyle, T. J. (2000): POPGENE 32, Microsoft Windows-based Freeware for Population Genetic Analysis, version1.32. Edmonton, Canada. - University of Alberta.

[30] Yuan, C. Y., Zhang, C., Wang, P., Hu, S., Chang, H. P., Xiao, W. J., Lu, X. T., Jiang, S. B., Guo, X. H. (2014): Genetic diversity analysis of okra (Abelmoschus esculentus L.) by inter-simple sequence repeat (ISSR) markers. - Genet. Mol. Res. 13: 3165-75.

[31] Yuan, Z., Chen, X., He, T., Feng, J., Feng, T., Zhang, C. (2007): Population genetic structure in apricot (Prunus armeniaca L.) cultivars revealed by fluorescent-AFLP markers in southern Xinjiang, China. - J. Genet. Genom. 34: 1037-1047.

[32] Zietkiewicz, E., Rafalski, A., Labuda, D. (1994): Genomic fingerprinting by simple sequence repeat anchored polymerase chain reaction amplification. - Genomics 20: 176183.

\section{APPENDIX}

Table A1. Selected ISSR primers

\begin{tabular}{c|c}
\hline Primer name sequence $\mathbf{5}^{\prime} \mathbf{-} \mathbf{3}^{\prime}$ & Primer name sequence $\mathbf{5}^{\prime} \mathbf{-} \mathbf{3}^{\prime}$ \\
\hline 801 ATA TAT ATA TAT ATA TT & 851 GTG TGT GTG TGT GTG TYG \\
802 ATA TAT ATA TAT ATA TG & 852 TCT CTC TCT CTC TCT CRA \\
803 ATA TAT ATA TAT ATA TC & 853 TCT CTC TCT CTC TCT CRT \\
804 TAT ATA TAT ATA TAT AA & 854 TCT CTC TCT CTC TCT CRG \\
805 TAT ATA TAT ATA TAT AC & 855 ACA CAC ACA CAC ACA CYT \\
806 TAT ATA TAT ATA TAT AG & 856 ACA CAC ACA CAC ACA CYA
\end{tabular}


807 AGA GAG AGA GAG AGA GT 808 AGA GAG AGA GAG AGA GC 809 AGA GAG AGA GAG AGA GG 810 GAG AGA GAG AGA GAG AT 811 GAG AGA GAG AGA GAG AC 812 GAG AGA GAG AGA GAG AA 813 CTC TCT СТC TCT CTC TT 814 CTC TCT CTC TCT CTC TA 815 CTC TCT CTC TCT CTC TG 816 CAC ACA CAC ACA CAC AT 817 CAC ACA CAC ACA CAC AA 818 CAC ACA CAC ACA CAC AG 819 GTG TGT GTG TGT GTG TA 820 GTG TGT GTG TGT GTG TC 821 GTG TGT GTG TGT GTG TT 822 TCT СТC ТCT СТC TCT CA 823 TCT СТС ТСТ СТC ТСТ СC 824 TCT CTC TCT CTC TCT CG 825 ACA CAC ACA CAC ACA CT 826 ACA CAC ACA CAC ACA CC 827 ACA CAC ACA CAC ACA CG 828 TGT GTG TGT GTG TGT GA 829 TGT GTG TGT GTG TGT GC 830 TGT GTG TGT GTG TGT GG 831 ATA TAT ATA TAT ATA TYA 832 ATA TAT ATA TAT ATA TYC 833 ATA TAT ATA TAT ATA TYG 834 AGA GAG AGA GAG AGA GYT 835 AGA GAG AGA GAG AGA GYC 836 AGA GAG AGA GAG AGA GYA 837 TAT ATA TAT ATA TAT ART 838 TAT ATA TAT ATA TAT ARC 839 TAT ATA TAT ATA TAT ARG 840 GAG AGA GAG AGA GAG AYT 841 GAG AGA GAG AGA GAG AYC 842 GAG AGA GAG AGA GAG AYG 844 CTC TCT CTC TCT CTC TRC 845 CTC TCT CTC TCT CTC TRG 846 CAC ACA CAC ACA CAC ART 847 CAC ACA CAC ACA CAC ARC 848 CAC ACA CAC ACA CAC ARG 849 GTG TGT GTG TGT GTG TYA 850 GTG TGT GTG TGT GTG TYC
857 ACA CAC ACA CAC ACA CYG 858 TGT GTG TGT GTG TGT GRT 859 TGT GTG TGT GTG TGT GRC 860 TGT GTG TGT GTG TGT GRA 861 ACC ACC ACC ACC ACC ACC 862 AGC AGC AGC AGC AGC AGC 863 AGT AGT AGT AGT AGT AGT 864 ATG ATG ATG ATG ATG ATG 865 CCG CCG CCG CCG CCG CCG 866 CTC CTC CTC CTC CTC CTC 867 GGC GGC GGC GGC GGC GGC 868 GAA GAA GAA GAA GAA GAA 869 GTT GTT GTT GTT GTT GTT 870 TGC TGC TGC TGC TGC TGC 871 TAT TAT TAT TAT TAT TAT 872 GAT AGA TAG ATA GAT A 873 GAC AGA CAG ACA GAC A 874 CCC TCC CTC CCT CCC T 875 CTA GCT AGC TAG CTA G 876 GAT AGA TAG ACA GAC A 877 TGC ATG CAT GCA TGC A 878 GGA TGG ATG GAT GGA T 879 CTT CAC TTC ACT TCA 880 GGA GAG GAG AGG AGA 881 GGG TGG GGT GGG GTG 882 VBV ATA TAT ATA TAT AT 883 BVB TAT ATA TAT ATA TA 884 HBH AGA GAG AGA GAG AG 885 BHB GAG AGA GAG AGA GA 886 VDV CTC TCT CTC TCT CT 888 BDB CAC ACA CAC ACA CA 889 DBD ACA CAC ACA CAC AC 890 VHV GTG TGT GTG TGT GT 891 HVH TGT GTG TGT GTG TG 892 TAG ATC TGA TAT CTG AAT TCC C 893 NNN NNN NNN NNN NNN 894 TGG TAG CTC TTG ATC ANN NNN 895 AGA GTT GGT AGC TCT TGA TC 896 AGG TCG CGG CCG CNN NNN NAT G 897 CCG ACT CGA GNN NNN NAT GTG G 898 GAT CAA GCT TNN NNN NAT GTG G 899 CAT GGT GTT GGT CAT TGT TCC A 900 ACT TCC CCA CAG GTT AAC ACA 